\title{
Academic Service Learning for Underprivileged Communities in Pakistan: Enhancing Development beyond Economics
}

\author{
Zehra Habib $^{\text {a }}$ \\ ${ }^{a}$ Associate Professor and Senior Fellow, Department of Education, IobM, Karachi, Pakistan \\ Email: zehra.habib@iobm.edu.pk
}

\begin{tabular}{l}
\hline ARTICLE DETAILS \\
\hline History: \\
Accepted 29 August 2021 \\
Available Online September 2021 \\
\hline Keywords: \\
Academic Service Learning; \\
Community Service; Development \\
beyond Economics
\end{tabular}

JEL Classification:

$P_{36, O 12}$

DOI: $10.47067 /$ reads.v7i3.400

\begin{abstract}
This study focuses on development of disadvantaged communities via an Academic Service Learning project, incorporated in the PhD coursework of a private university. School teachers from an underprivileged community in a charitable village school of Baluchistan were given training by the students after doing interviews for needs analysis and developing and implementing a workshop based on their needs. As part of the workshop evaluation process, teachers' perspectives were examined after teachers had incorporated the workshop strategies in their classrooms. Findings were highly positive, because teachers demonstrated enhancement in learning and constructive gain in scholarship which they could transfer to students and to other teachers in the community. Data from students who had carried out the project, accentuated improved learning and a keen desire for voluntary participation in service learning projects for helping underprivileged communities. This study not only contributes to the body of literature in academic and community service learning in the Pakistani educational context, but elaborates on the value of factors beyond economics for advancement of deprived segments of society.
\end{abstract}

(C) 2021 The authors. Published by SPCRD Global Publishing. This is an open access article under the Creative Commons AttributionNonCommercial 4.0

Corresponding author's email address: zehra.habib@iobm.edu.pk

\section{Introduction}

In the globalized and digital age, students consider theory based coursework as inadequate in the cutting edge and competitive international scenario because they cannot practically apply the knowledge they have gained. They are looking for additional value in their education to make them more employable in the competitive market (Tomlinson, 2008). Many psychologists such as Piaget (1959), Dewey, (1960) and Vygotsky (1962) put forward social constructivists learning theories that accentuate the significance of social immersion and dynamic involvement of individuals in the group learning process in the construction of knowledge (Tokke, 2017). No longer is it adequate for graduates to simply depend on learning of theory and test taking (Andrews \& Higson, 2008). However, in a developing country like Pakistan, Academic Service Learning (ASL) is an emerging and relatively new concept in the higher educational context. 


\section{Review of Economics and Development Studies, Vol. 7 (3) 2021, 453 - 464}

Academic Service Learning (ASL) is a teaching and learning approach that incorporates significant communal work at charitable organizations or public service places to enhance learning (Hayward, 2014; Sass \& Coll, 2014). ASL is a channel between university and community that connects the real world to theoretical textbook knowledge and contributes to civic development. (Bansal et al., 2012; Resch \& Schrittesser, 2021). Currently universities are focusing on fulfilling community needs and combining these with academic goals, leading to positive outcomes for both, i.e., wide-ranging segments of society and the students (Lieberman, 2014; Trigos et al., 2020).

Development is often linked to economics and is considered to be the generation of wealth from which communities profit. It is thus a venture for advancing the economy and contributing to the cumulative and prosperous growth of citizens of a country (California Association for Local Economic Development, 2021). However, the delineations of development go beyond its economic aspect and scholars have defined it as a process which leads to advancement and makes a headway towards constructive transformation, adding to the environmental and societal enhancement of a community or an individual (SID for International Development, 2021). Though economic development is of vast significance for any country, long term development is not possible if health and education of the common man are neglected. Thus the main purpose of development is to achieve an improved life for the masses (Darling-Hammond, 2020; Islam \& Ali, 2015).

Academic Service Learning is a means of connecting university faculty and students to grassroots populaces, but in Pakistan, this is a relatively new model. Even though some universities are integrating it in their syllabi, the degree of success is not equal for all (Morrison, 2016). The Pakistani educational milieu is deficient in linking learning with real life contexts, as such, it is imperative that academic learning is assimilated with community service (Aslam, Jaffery \& Zaidi, 2011). ASL is a powerful tool for helping disadvantaged segments of societies, and further research is needed to determine their long-term impacts (Berg, et al., 2016). In this global scenario, it is the responsibility of higher education institutions to concurrently disseminate knowledge and raise awareness of students regarding civic duties for service and development of disadvantaged communities (Plater, 2011). Particularly, "given the host of social problems Pakistan faces, it is important to increase awareness among its youth about their civic role in society" (Aslam, Jaffery \& Zaidi, 2011, p. 524).

The current research posits that integrating ASL in the educational context, particularly at the tertiary level is crucial if education is to be imparted from the perspective of developing proficient and responsible citizens. Thus six PhD students enrolled in a curriculum oriented course of the Education Department of a private university carried out a service learning project in a charitable school in a village of Baluchistan province. Baluchistan is a highly underdeveloped province of Pakistan, and its villages are even more backward and deprived of educational facilities than any other rural areas of the other three provinces (Sarfaraz \& Nomani, 2020). Despite an educational emergency declared by the provincial government, data indicate that 963 out of 13,000 schools in the province are not even operational. Statistics of $2016-17$, indicate that 22.6 million children are out of school in Baluchistan which takes it to a high of 66 percent. There is very limited concept of girls' education in rural Baluchistan and an almost non-existent educational ethos in its rural districts, depriving the children of quality education from public run schools (Baloch, 2017). 40 percent of children do not go to school in Baluchistan and until government, civil society and NGOs do not make conscious efforts to improve the state of education in that province, the situation will continue to be distressing (Quetta Voice, 2020). Thus the rationale for this research to select a charitable school in a rural district of Baluchistan for the Academic Service Learning project is because the province is lacking in educational facilities.

\section{Literature Review}

Literature on ASL is disposed more towards its benefits to students and has focused less on community development (Gellar et al., 2016). Yet service learning is most significant when school - community liaisons in poverty stricken, underdeveloped areas, help meet the socio-emotional needs of the population, be they students, teachers or societal members in any other capacity (Sanders, 2003). Communal involvement and development pedagogies are often called Academic Service Learning which combine learning and development so that all parties involved may benefit from the service (Atwell \& Schlund, 2021). Opportunities for community-university collaborations improve students' capacity to realistically implement their learned skills in real world settings and 


\section{Review of Economics and Development Studies, Vol. 7 (3) 2021, 453 - 464}

underdeveloped groups value the human resources and expertise needed to achieve their goals (Bandy, 2011). However, Aslam et al. (2011) declare that there is a dearth of service learning projects for benefits of society in Pakistan, though the demand for such projects is on the rise (Morrison, 2016).

There are several empirical studies in the international context, demonstrating the value of service learning, aiding growth not because of economic incentives but due to educational contribution. Such studies demonstrate the value of service learning from the developmental perspective of disadvantaged echelons of society.

In a qualitative study, Resch and Schrittesser (2021) conducted semi-structured interviews with 13 teachers to explore how service learning could assist professional teacher development in Austria. Their findings reflected that service learning helped connect theory with practice, and improved pedagogical skills of teachers. The most crucial finding of the study related to service learning as a tool for engagement with community because the participants emphasized the linkage between service learning and community development, highlighting "public welfare, societal benefits, social participation and responsible citizenship" (p.7) as constructive factors of service learning.

Another qualitative study was conducted in the Malaysian higher education context (Yusof et al., 2020), involving both students and teachers, underlining their perspectives on challenges encountered while conducting service learning. Individual, face to face interviews were conducted with the teachers, while focus group interviews were held with the students. Findings indicated that students found a huge gap between theory and practice and were desirous of having more service learning experiences incorporated in the curriculum. Challenges that teachers encountered included a lack of structural support and the implementation aspects, particularly from the standpoint of time, preparation and delivering the task.

Richard et al. (2017) conducted a quantitative analysis, using data from 30 campuses in the United States to examine whether service learning conducted during the years of study in higher education led to more civicmindedness after graduation or post-graduation. Using a quantitative scale, the authors studied curricular and co-curricular aspects of service learning programs. Findings demonstrated that civic mindedness was associated with recurrent civic action if students had been exposed to ASL during their college or university days. Results further indicated that obligations to development of the lower strata of society via service learning depended on the number of opportunities provided to students to engage in ASL related courses. Thus course based ASL had contributed to creating a zest amongst students for civic development even after completion of university education.

Regarding empirical researches in service learning in the Pakistani context, (Ahmed, et al., 2019), conducted a quantitative study with 315 respondents which examined standpoints of teachers of vocational training institutes and outcomes of service learning experienced by vocational training students. Findings indicated that outcomes of partaking in service learning amplified students' comprehension of course content via experiential learning and contributed to development of social skills, augmenting a zeal in students for community service. Furthermore, participation in service learning enhanced students understanding of issues that affiliates of vocational academia faced.

In a study conducted in Lahore, (Aslam et al., 2011) implemented a service learning project in a health center for young women from the grassroots level of society. 13 students from a girls' college aided to raise awareness of 48 women participants regarding Iron Deficiency Anemia (IDA). Data from students revealed a huge improvement regarding bonding with the women and an increased consciousness that they could play a role in the development and betterment of society. The women enrolled from the community affirmed that the service learning project had helped vastly in improving their knowledge regarding iron deficiency anemia (IDA) and its deterrence. The positive effect of the project encouraged faculty for inclusion of service learning in the upcoming curricula of the college.

Findings of a qualitative study conducted by (Iqbal et al., 2021) in regions of Punjab, with 30 elementary 


\section{Review of Economics and Development Studies, Vol. 7 (3) 2021, 453 - 464}

school teachers from vocational training institutes indicated positive results via service learning. The teachers considered planning as the most important phase of service learning followed by duration of the project. If the duration would be long enough, then participants of the project would achieve more. Training was another factor very important for those who were going to impart the service learning. Teachers were also of the opinion that needs of the population for whom service learning was being implemented had to be focused on prior to commencement of the project. Findings also indicated that collaboration was the strongest element in success of service learning projects, for example, establishing a link among the participants and the practitioners. Reflection was another factor that surfaced in the findings because when students reflect on their service learning experience, it initiates their enthusiasm for community development and their responsibility as active citizens.

\section{Methodology}

Qualitative methodology was apt for this research because this approach focuses on aspects in their natural settings and endeavors to interpret phenomena "in terms of the meaning people bring to them" (Denizen \& Lincoln, 2005, p.3). Patton asserts that qualitative research allows for detailed and in depth study of issues (Patton, 2002).

\section{1 $\quad$ Setting}

A charitable school in a village district of Baluchistan was the setting for this research study where the ASL project was implemented. This school had initially started with a bamboo mat, a blackboard and a few slates. With efforts from the philanthropists who run the school, it now has a full-fledged, well-furnished building and caters to students up to grade five. This school offers education to both boys and girls, including provision of books and uniforms. Furthermore, the school prepares students for the Baluchistan Board Exam, because in Baluchistan, students of grade five have to sit for a Board exam in order to be promoted to grade six. After clearing the exam, the students have to transfer to a public school in a nearby area, should they be interested in further education.

As a community service, the PhD in education program, conducted a workshop for teachers in the school, based on curriculum content implementation. After obtaining consent from the trustees, the principal and the teachers of the school, the community service was conducted in different phases. However, there were the restrictions of staying within the confines of the curriculum prescribed by the Board of Education, Baluchistan. Within these challenges and limitations, students aimed for professional development of the teachers, endeavoring to train them for activity based and communicative teaching.

\subsection{Participants}

Besides the six PhD students of a private university in Karachi, the principal of the school and five teachers who taught grade five students were participants in this research. The subjects taught by the teachers were Maths, English, Islamiyat, Science and Social Studies. Table one below explains demographics of the principal and teacher participants.

Table One Denotes the Demographics of the Principal and the Teachers

\begin{tabular}{|c|c|c|c|}
\hline \multicolumn{4}{|l|}{ Participants } \\
\hline Participants & $\begin{array}{l}\text { Educational } \\
\text { Qualifications }\end{array}$ & Subjects Taught & Experience \\
\hline Principal & M.Ed. & ---- & 19 years \\
\hline Teacher & B.Ed. & Maths & 5 years \\
\hline Teacher & B.Ed. & Islamiyat & 9 years \\
\hline Teacher & $\mathrm{BA}$ & English & 3 years \\
\hline Teacher & Intermediate & Soc. Studies & 5 years \\
\hline Teacher & Intermediate & Science & 6 years \\
\hline
\end{tabular}




\section{Review of Economics and Development Studies, Vol. 7 (3) 2021, 453 - 464}

\subsection{Tools for Data Collection}

The tool used for data collection from the principal and the five teachers of the charitable school were individual, in-depth semi-structured interviews. All interviews were conducted in Urdu and were recorded with the participants' consent. The recorded interviews were later translated and transcribed in English recorded conducted in Urdu and then translated and One of the students interviewed the principal and each of the other five students interviewed a teacher. Individual semi structured interviews are not only flexible and provide indepth information, the value of such interviews is also that these can be complemented by follow up questions (DeJonckheere \& Vaughn, 2019). Data collection tools also included a focus group interview with the PhD students who implemented the ASL project. The research was divided into four different phases and a description of each phase follows below:

\subsection{Phase One}

In the first phase, the students interviewed the principal and the teachers to find out their needs in order to develop a workshop for implementing the curriculum. Need analysis pertains to comprehending the needs of the learners in order to design a training program made precisely in alignment with their requirements (Bleich, 2018). Needs analysis is the most important and pertinent step prior to launching a workshop or any training program, because this helps in identifying the lacks and gaps and demarcates the areas that should be focused on for the workshop (Morrison, 2020).

\subsection{Phase Two}

The six PhD in Education students, under guidance of their faculty, developed a workshop based on the data derived from the needs analysis conducted in phase one. The contents, activities and material involved catered to the needs of the teachers and subjects they taught. The content and activities of the workshop were discussed thoroughly in class prior to the implementation and feedback from the course supervisor and peers was incorporated to ensure the productivity of the project. Keeping in mind the background of the school, the students made sure that the materials used for the workshop project were cost effective. Enthusiasm of the students was remarkable at this stage, because each one was contributing ideas and volunteering to provide materials that were cheap in cost, yet beneficial for activities. This workshop was based on Bloom's Taxonomy and incorporated latest and innovate teaching techniques and was student centered. However, the changes introduced were gradual, keeping in mind the culture of rural Baluchistan, so that the teachers may not feel overwhelmed by the change.

Since pedagogy is one of the most significant aspects of curriculum implementation, students planned activities that would help teachers think out of the box and introduce change in their pedagogical practices even though the change would be evolutionary and a small one. For English, the skill of writing was most focused on due to the request of the English teacher during the needs analysis segment. For Islamiyat, the units chosen from their text were Rehamdili (kind heartedness) and Ikhlakiyat (good behavior). The students planned that these topics should be taught through role plays, as this would develop their interest and would also involve them in the role play. For Maths, the problem solving method was used for solving HCF and LCM, rather than the traditional method and emphasis was laid on understanding the basic principles. For science, out of door activities were planned for taking children out on the ground outside the classroom and teaching them about plants. Also, low cost, no cost apparatus was used for demonstrating the concept of molecules. Lastly for Social Studies, the chapter on Pakistan's Parliament was chosen and highly interactive and role play activities were developed to make students comprehend the concepts of voting and the formation of parliament.

The teachers were given one month for incorporating training of the workshop in their pedagogical practices in classroom.

\subsection{Phase Three}

The third phase of the research was conducted after the teachers had implemented strategies from the workshop with their students. This phase comprised of interviews with the principal and teachers for workshop evaluation and to comprehend if the teaching approaches of the workshop had a positive impact on the teachers and their students. 


\subsubsection{Phase Four}

The fourth and final phase of the research comprised a focus group interview with students to understand their perspectives of the entire ASL project and to help them reflect on their experience of the hands on learning project.

Figure 1 describes the four phases of the ASL project

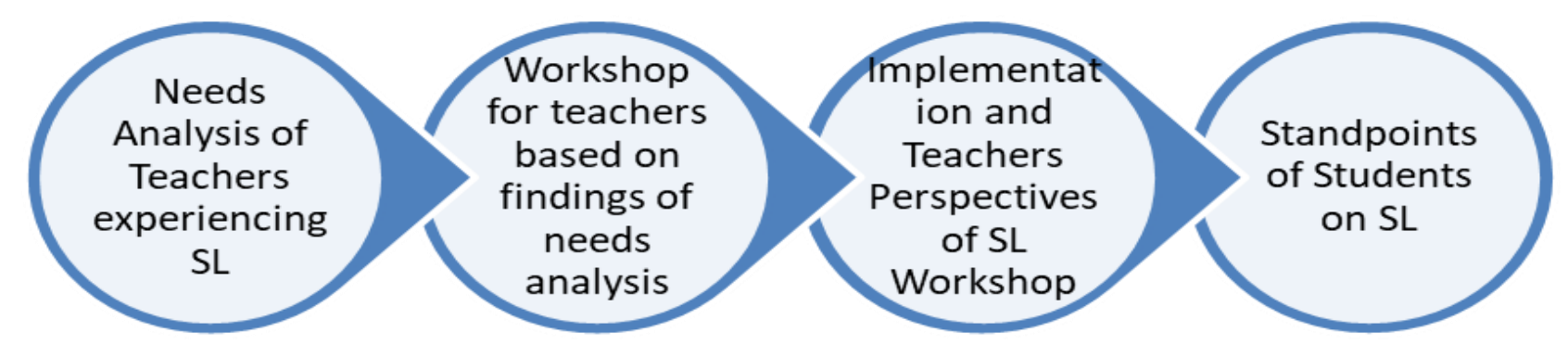

\section{Findings and Discussion}

\subsection{Findings from Needs Analysis}

The principal of the school during her interview for needs analysis lamented that there were no professional training facilities available for the teachers in the remote areas of the province. Thus teachers taught via age-old traditional methods and there was nothing teachers did to enhance students' interest in learning. In the words of the principal:

I was teaching in Karachi for a long time; so I come from an urban setting; but I took up position of principal here because I wanted to help education in the remote areas. I try to train teachers myself by sharing with them what I have learnt; but that is not enough. I am not aware of the latest techniques myself. Our greatest needs are two: training teachers to teach with new methods and particularly, helping our English language teachers, because they are the weakest here. We want to improve English language of the students because it is only when children are well versed in English that they can progress. I strongly feel that if these children have to rise, they need to be proficient in English.

Four of the five teachers, during their individual interviews regarding their needs in the teaching set up, shared perspectives, ranging from lack of professional training, to dearth of teaching methodologies. The fifth teacher, who taught Islamiyat, had a totally different perspective. Standpoints of all teachers are being discussed below.

The Social Studies teacher expressed the thought that there should be different teachers teaching different grades because it is too much for her to be teaching Social Studies to students of all five grades in school. Concerning her pedagogical needs, she reflected that she only teaches what is in the textbook but she has been searching the net and is aware that there are newer techniques of teaching. An excerpt from her interview highlights the key points regarding her pedagogical needs: 


\section{Review of Economics and Development Studies, Vol. 7 (3) 2021, 453 - 464}

I only teach what is written in the textbook. The children find it so boring, but then what else should I do? I know some technology and have been searching the web and reading and have found that there are new ways to teach and to raise interest of students. How can I do that? We need proper training. There is lack resources, even though the lady who runs this school is very generous and tries to provide as many resources as possible, but she cannot take all the burden on herself.

The Maths and Science teachers had identical perspectives to share regarding their teaching needs. They lamented that they did not get any training in the remote rural areas. They considered that even though this was a private, charitable school, it was the duty of the government to provide teachers with training regarding new techniques to teach. Like their peer who taught social studies, they too were desirous of knowing how to make the courses more interesting for the students because the children did rote learning, which according to them, did not help the cause of education.

The most prominent perspective was that of the English teacher who complained that children did not know even to write a proper sentence in English and they were expected to write a paragraph for the board exam of grade five. In her words:

The students suffer most while learning English. My English is ok but it is not that good. I need training to teach children how to learn English. You know, we have to make children sit for a board exam in class five in Baluchistan and these children have to write a paragraph but they cannot speak or write one sentence correctly. So the only solution is that there are three paragraphs already given in their textbook and one of these comes in the exam, so the children learn the paragraphs by-heart and then write down as much as they can in the exam. Even learning by heart is extremely difficult for them. So I want to know how to make them write. One of my cousin's teaches in Karachi, and even though she teaches at a government school, she says that the children understand some English...here, it is hardly a few words.

Among the five teacher participants, only the Islamiyat teacher who had been associated with the school for several years, declared that the Islamiyat textbook was good and that the children were learning. In his perspective:

We have a good Islamiyat textbook and the children are learning the subject well. I really cannot think of how else we might improve our teaching, but yes, if you have new ways to offer, I'll be interested to know what these are.

Doing needs analysis contributed majorly to deciphering teachers' needs, according to which the workshop was then planned and prepared. Previous literature corroborates that conducting need analysis is the most significant step prior to conducting any professional development program. This is so because identifying problems and then looking for solutions is better than planning a training which may not help the recipients. Conducting a needs analysis helps to identify areas which trainers may not have considered (McPheat, 2020; Morrison, 2019). Thus in this research, needs analysis were crucial because it yielded results based on which the workshop was developed and delivered by the PhD students.

\subsection{Teachers Responses during the Workshop}

As explained in the methodology section, the workshop based on Bloom's Taxonomy was conducted keeping in mind the needs of all the teachers. When asked if they were aware of Bloom's Taxonomy, all five respondents commented that though they had studied it, they could not recall its contents. Four out of five teachers were highly responsive and took a keen interest in the workshop. The English teacher was particularly excited with ideas regarding novel techniques of teaching writing and commented that "I never knew that teaching English writing could be so interesting." It was the Islamiyat teacher who raised the most objections to the workshop activities saying, "it will be very difficult to implement all this role play and all the activities that 


\section{Review of Economics and Development Studies, Vol. 7 (3) 2021, 453 - 464}

you are showing and I don't think students will be interested in all this." However, as per the requirement of the research, he assured that he would "try to" implement the activities in class because he had to report to the principal of the school, regarding implementation.

\subsection{Teachers Responses after Implementation of Workshop Activities}

The post workshop implementation findings from teachers reported a positive change not only in their outlook towards teaching but also how they had noted a positive change in students' attitude towards studies because of their active involvement in classroom activities. The Maths teacher had implemented all activities to the hilt and expressed how keen students were to study Maths now and how well they had performed in their monthly test after doing activity based learning. In her words:

If one workshop could bring so much difference in the students, others of the similar kind could help so much. The students are taking such keen interest. They want to participate in activities! They are not shy any more. I used to find them to be very shy and not responsive...but not now! They have participated in activities and have in fact, performed very well in their test which I gave them after implementing workshop learning. But I have to say that one workshop will not suffice...we need proper training. If your institute establishes a link with ours, if your students keep coming here, it would do us a world of good. We could also train other teachers following your mode of workshop and we can benefit the entire community this way.

The Social Studies teacher had a positive outlook but with some reservations: Her reservations are expressed below:

It was an excellent workshop and we benefitted a lot from it....but, the activities done in the workshop as far as social studies is concerned were too many and though I was able to do some of these during the one month we got, I needed more time. The students of course enjoyed doing activities about their civic responsibilities but there was no time to implement the activities regarding parliament. I want to add that this type of training should not stop. Instead of one workshop, we need at least 6 months of training. This would be very beneficial for development of the entire community of students here. After all, if we have good educated students, then the nation will develop well.

The Science teacher took the children out in the field to teach them about plants and other natural elements and she too said that the students had performed better on the test. She also demonstrated the experiment about the molecules and expressed that students particularly enjoyed the role play of scientists trying to explain the concepts of atoms and molecules.

The English teacher realistically admitted that though students who had actually disliked the English class prior to it being activity based, were now taking interest in learning to write a paragraph, though their progress was "very slow," and they were yet very far from learning paragraph writing. because they were exceptionally weak in English. Moreover, like her counter parts, she too expressed the hope that workshops would not stop and the training would continue.

The most surprising findings emerged from the data of the Islamyiat teacher. As reported earlier, he was the one who had most reservations regarding the workshop and who had said that students would not be interested and that he will not find the time to implement the activities explained in the training. The teaching outcomes for him were most positive and he was most enthusiastic regarding implementing what he had learned. An excerpt from his interview will shed light on his views:

I cannot believe it! I thought the students would shy away from the activities and the role play and I had thought that they were content to learn from their textbook but I got just the opposite reaction from the students! They all wanted to take part in the role play and could not wait for their turn. Each one of them took keen interest in the activities and so I must say that I was mistaken that they would not be interested. Such workshops should continue for us so that 


\section{Review of Economics and Development Studies, Vol. 7 (3) 2021, 453 - 464}

both teachers and students can benefit.

The findings from this study are similar to findings of previous research. Resch and Schrittesser (2021), had found in their study that teachers who were part of a service learning project during their professional development had derived huge benefits from such professional training as did the teacher participants in the current research. Challenges encountered by teachers in the present study are similar to challenges faced by teachers in previous empirical researches. For example, one teacher complained of lack of time for preparing and carrying out the project activities in class, implementing the project activities. Similarly, findings of Yusuf et al (2020) indicate that teachers faced the issue of time management in delivering activities and strategies studied during training.

Moreover, teachers' emphasis in their interviews regarding continued professional development and not just a random workshop as indicated by findings, has been underscored by several other researchers. Continued professional development helps teachers during their entire career and continued learning by teachers is key for achieving educational goals (Antley, 2020; Karlberg \& Bezzina, 2020; Mizell, 2010).

\subsection{Findings from Students}

Data from student's focus group interview at the end of the semester regarding their academic service learning project was highly positive and very encouraging. All six students expressed satisfaction of having done hands on experiential learning and enthusiastically acknowledged that they had learnt much more than if they would have simply studied theory. More importantly, they acknowledged that they were more aware of the community needs regarding education in rural areas of Baluchistan and expressed the desire for further academic learning experiences and admitted that hitherto, they had not realized nor recognized the need of community development and education dissemination in the rural areas of the country. In fact, they wanted to offer voluntary services for future educational development in this and other parts of the country.

An excerpt from what a student said in the focus group interview is included below:

I wish we could have project based learning in all our courses. We have learned so much more this way...and going to Baluchistan, getting out of our shells and trying to understand their educational needs has made such a difference. I would like to volunteer my services for further helping the teachers in this and in other rural communities because better teachers will generate better students and together they could contribute to developing a community of refined citizens.

Another student expressed her take on the entire service learning experience in the following way:

I could not get enough of it! I admit that initially, when we were developing the workshop content and materials, it was a lot of hard work, but the hard work has paid off in more ways than one: we have acquired so much more knowledge than we could have through theory based teaching. Also, to see the enthusiasm of the teachers, to see their success and the glow on their faces after implementation, was in itself a success story. I want to volunteer my services for this school, for NGOs and for any other educational projects where I can be of any help. We, as students need to work for the betterment of underprivileged communities...that is one super lesson I've learned from this experience.

The findings from students' data corroborate the findings of previous studies conducted by Resch and Schrittesser (2021), Ahmed et al., (2019) and Richard et al., (2017) wherein service learning generated civic mindedness and enthusiasm among students to volunteer their services for community development. In the study by Aslam et al. (2011), students' knowledge increased due to experiential and hands on learning, similarly in the current study, students declared that they had grasped a lot more via practical learning projects than they could if the curriculum course had been simply theory based. All these researchers, including the current study point in the same direction, i.e. service learning is not only beneficial for students but also from the perspective 


\section{Review of Economics and Development Studies, Vol. 7 (3) 2021, 453 - 464}

of community development, particularly if the community is disadvantaged and deprived of facilities for suitable education.

\section{Limitations}

The Academic Service Learning project yielded positive results albeit with some limitations. We had to restrict our curriculum implementation strategies to the prescribed Baluchistan Board curriculum and could not add creative content to the syllabi. Furthermore, this research was based on a single service learning project and applied only at one school. Service learning projects need to be designed and carried out regularly in urban and rural sectors for educational development of communities living there.

\section{Conclusion and Recommendations}

This research highlights the contribution of service learning in academia for community development and advocates a roadmap for integrating community development projects in the higher education milieu in Pakistan. Such ventures also provide encouragement to students for volunteering their services to help less privileged communities because there are factors beyond economic elements which can enhance development. It is also recommended that a policy should be formulated at the governmental level whereby professional training could be given to teachers in rural areas so that they can transfer their improved pedagogical skills to students in rural communities who form an important segment of the Pakistani community. A public and private sector partnership is also advocated whereby both sectors can contribute to education via service learning projects in the poorer areas of Pakistan and thus help development because education is the prime factor leading to development in any country.

\section{References}

Ahmed, I., Said, H., \& Mohamad Nor, F. (2019). Exploring service-learning practices: Evidence from Pakistani vocational education. Malaysian Journal of Learning and Instruction, 16(2), 125-154.

Andrews, J., \& Higson, H. (2008). Graduate employability, "soft skills" versus "hard” business knowledge: A European study. Higher Education in Europe Special Issue: Employability, Mobility and the Labor Market,33(4), 411-422.

Antley, T. (2020, July 16). What is professional development and why is it important? Webce. http://webce.com/news/2020/o7/16/professional-development

Aslam, R. Jaffery, T., \& Zaidi, Z. (2011). Service learning: Increasing civic responsibility in Pakistani students. Medical Education, 45, 508-535.

Baloch, M.G. (2017). Abysmal condition of education in Balochistan needs attention. In Balochistan Times, 9-9-2017. Retrieved from thebalochistanpoint.com/abysmal-conditionof-education-in-balochistan-needs-attention/

Bandy, J. (2011). What is service learning or community engagement? Vanderbilt University Center for Teaching. https://cft.vanderbilt.edu/guides-sub-pages/teaching-throughcommunity-engagment

Bansal, P., Bertels, S., Ewart, T., MacConnachie, P.,\& O’Brian, J. (2012). Bridging the researchpractice gap. Academy of Management Perspectives,26(1),73-92.

Berg, D. R., Lee, T., \& Buchanan, E.A. (2016). A methodology for exploring, documenting, and improving humanitarian service learning in the university. Journal of Humanitarian Engineering, 4(1), 1-7.

Bleich, C. (2018, April 18). How to conduct a training needs analysis. Edgepoint learning. www.edgepointlearning.com/blog/training-needs-analysis

California Association for Local Economic Development (2021). Caled. www.caled.org/economics-development-basics/

Darling-Hammond, L., Flook, L, Cook-Harvey, C., \& Osher, D. (2020). Implications for educational practice of the science of learning and development. Applied Developmental Science,24(2), 


\section{Review of Economics and Development Studies, Vol. 7 (3) 2021, 453 - 464}

97-140. https://doi.org/10.1080/1080/10888691.2018.1537791

DeJonckheere M., \& Vaughn, L.M. (2019). Semistructured interviewing in primary care research: A balance of relationship and rigour. Family Medicine and Community Health. http://fmch.bmj.com/content/fmch/7/2/eoooo57.full.pdf

Denizen, N.K., \& Lincoln, Y.S. (Eds.). (2005). The Sage handbook of qualitative research (3rd. ed.). Sage Publications Ltd.

Geller, J.D., Zukerman, N., \& Seidel, A. (2016). Service-Learning as a catalyst for community development: How do community partners benefit from Service-Learning? Education and Urban Society,48(2), 151-175. http://doi.org/10.1177/o013124513514773

Hayward, M. S. (2014). Service learning in the community college: Drive to employment. Community College Journal of Research and Practice,38(9), 838-841. http://doi.org//10.1080/10668926.2013.790858

Iqbal, A., Saeed, M., \& Ullah, Z. (2021). A qualitative study of factors influencing service-learning implementation in vocational education field of Pakistan: Teachers' perspectives. Liberal Arts \& Social Sciences International Journal, 5(1), 55-74. http://doi.org/10.47264/idea.lassij/5.1.5

Islam, K.M., \& Ali, A. (2015). Recognizing development beyond economic growth: By analyzing impact of inequality on development. International Journal of Research in Business and Technology,7(3), 928-938.

Karlberg, M., \& Bezzina, C. (2020). The professional development needs of beginning and experienced teachers in four municipalities in Sweden. Professional Development in Education,1-19. http://doi,org./10.1080/19415257.2020.1712451

Lieberman, D. (2014). The ABCDs of service-learning: Who is serving whom? Journal of Human Education Outreach and Engagement, 18(4). 7-15.

Matthew, A., \& Schlund, J. (2021, July 26). Schools must connect learning to real-world experience: Service learning can help. Edsurge.http://edsurge.com/news/2021-07-26schools-must-connect-learning-to-real-world-experience-service-learning-can-help

McPheat, S. (2020, December, 14). 6 benefits of conducting a training needs analysis for your business. MTD. www.http://mtdtraining.com/blog/benefits-of-training-needs-analysis.htm

Mizell, H. (2010). Why professional development matters. Learning Forward. http://learningforward.org/wp-content-uploads/2017/o8/professional-developmentmatters-pdf

Morrison, E.A. (2016). At a crossroads: Pakistani college students' perspectives on service and service learning,(4)1, 2374-9466.

Morrison, K. (2019, January 17). What training needs analysis is and how it can benefit your organization. Elearning Industry. www.elarningindustry.com/training-needs-analysisbenefit-organization

Patton, M.Q. (2002). Qualitative research \& evaluation methods. Sage

Plater, W. (2011). The context for international service-learning: An invisible revolution is underway. In R. Bringle, J. Hatcher, \& S. Jones (Eds.), International service learning (pp.2656). Sterling, VA: Stylus.

Quetta Voice (2020, December 13). Out of school children in Balochistan. Quetta Voice.http://quettavoice.com/2020/12/13/out-of-school-children-in-balochistan/

Resch, K., \& Schrittesser, I. (2021). Using the Service-Learning approach to bridge the gap between theory and practice in teacher education. International Journal of Inclusive Education. 1-13. http://doi.org/10.1080/13603116.2021.1882053

Richard, D., Keen, C., Hatcher, J.A., \& Pease, H.A. (2017). Pathways to adult civic engagement: Benefits of reflection and dialogue across difference in higher education service-learning 


\section{Review of Economics and Development Studies, Vol. 7 (3) 2021, 453 - 464}

programs. Michigan Journal of Community Service Learning, 23(1), 60-74.

Sanders, M.G. (2003). Community involvement in schools: From concept to practice. Education and urban society,35, 161-180.

Sarfaraz, H., \& Nomani, U. (2020). Balochistan Strategy. Pakistan Poverty Alleviation Fund. PPAF. http://ppaf.org.pk/doc/Balochistan\%205Strategy\%20_202opdf

Sass, M.\& Coll, K. (2014). The effect of service learning on community college students. Community College Journal of Research and Practice,39(3). http://doi.org/10.108o/10668926.2012.756838

SID for International Development. (2021, February 17). What is development? SID for International Development. www.sid-israel.org/en/what-is-development

Tokke, C. (2017). Academic service learning using affinity groups outside the box business: A pedagogy model for community college business students. Community College Enterprise, 26-42.

Tomlinson, M. (2008). “The degree is not enough": Students' perceptions of the role of higher education credentials for graduate work and employability. British Journal of Sociology of Education, 29(1), 49-61. Doi: http://doi.org/10.1080/01425690701737457

Trigos-Carrillo, L., Fonseca, L., \& Reinoso, N. (2020). Social impact of a transformative service learning experience in a post-conflict setting. Frontiers in Psychology, 11. http://doi.org/10.3389/fpsyg.2020.00047

Yusof, N., Ariffin, T., Hashim, R.A., Nordin, H., \& Kaur, A. (2020). Challenges of service learning practices: Student and faculty perspectives from Malaysia. Malaysian Journal of Learning and Instruction, 17(2), 279-309. 